Effect of slope and depth on soil chemical properties of a typical alfisol

Utjecaj nagiba i dubine na kemijska svojstva tipičnog alfisola

Anwanane, N.B., Affinnih, K.O., Olaniyan, J.O.

Poljoprivreda/Agriculture

ISSN: $1848-8080$ (Online)

ISSN: 1330-7142 (Print)

http://dx.doi.org/10.18047/poljo.23.2.1

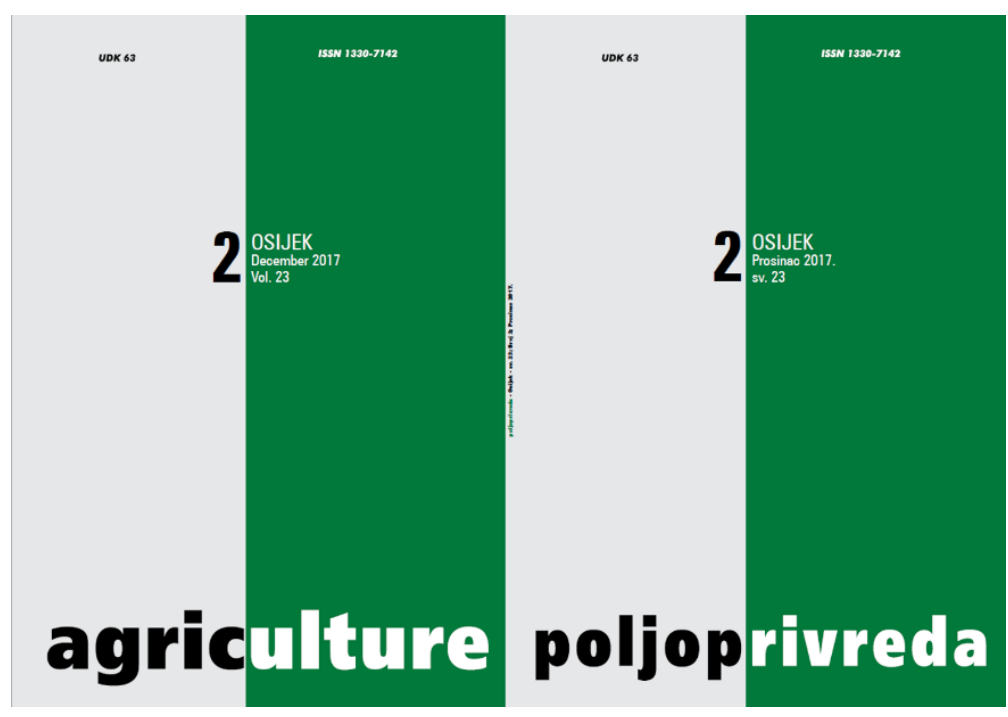

Poljoprivredni fakultet u Osijeku, Poljoprivredni institut Osijek

Faculty of Agriculture in Osijek, Agricultural Institute Osijek 


\title{
EFFECT OF SLOPE AND DEPTH ON SOIL CHEMICAL PROPERTIES OF A TYPICAL ALFISOL
}

Anwanane, N.B., Affinnih, K.O., Olaniyan, J.O.

Original scientific paper Izvorni znanstveni članak

\section{SUMMARY}

\begin{abstract}
Management options proffered with respect to the chemical properties along a toposequence are a key to sustainable crop and soil productivity since nutrient status and soil properties are related to topography of the land area. A study was conducted to evaluate the effect of slope and depth on selected soil chemical properties at the University of Ilorin Teaching and Research Farm in 2013. Three points: upper, middle and bottom slope, along a toposequence with an average distance of $200 \mathrm{~m}$ apart were delineated and sampled for soil analysis at depths of 0-30 cm, 30-60 cm and 60-90 cm using core sampler and auger. Soil chemical properties which included $\mathrm{pH}$ in water, $\mathrm{pH}$ in $\mathrm{KCl}$, electrical conductivity, organic matter, total nitrogen, available phosphorus, exchangeable bases (Ca, Mg, K, Na), exchangeable acidity, effective cation exchange capacity, base saturation, exchangeable sodium percentage and sodium adsorption ratio were determined in the laboratory/ computed afterwards. Data from the analysis were subjected to ANOVA using $2 \times 3$ factorial combinations of factors slope and depth - in randomized complete block design (RCBD) with five replicates. Results on the effects of slope and soil depth on soil chemical properties showed that soil depth affected all the measured soil chemical properties except exchangeable sodium. The $\mathrm{pH}$ (both in water and KCl), electrical conductivity, available phosphorus and exchangeable potassium were not affected by slope. Also, pH, exchangeable magnesium and sodium were not affected by the interaction between the effect of slope and soil depth.
\end{abstract}

Key-words: slope, depth, chemical properties, Alfisol

\section{INTRODUCTION}

Topography is a major factor which controls most surface processes taking place on earth, i.e. soil formation and soil development. Topography influences soil chemical and physical properties and also pattern of soil distribution over landscape (Kalivas et al., 2002; Esu et al., 2008). For instance, the negative impact of rainfall is higher where landscape is sloppy with regards to erosion and deposition. Soils on hill slopes differ from those at summits or valleys in terms of moisture distribution, soil depth, cations distribution, and organic matter contents (Asadu et al., 2012). Ogban et al. (1999) reported that nutrient status and soil properties are related to topography of the land area. A wide variation in phosphorus $(\mathrm{P})$ distribution along a toposequence in southeastern Nigeria; where total $P$ was found to be highest at the upper slope and lowest at the middle slope was observed by Osodeke and Osondu (2006).

Organic matter varies with landscape position (Bhatti et al., 1991). In addition to the soil organic matter which varies with landscape, landscape influences soil texture, penetration resistance (Bruand et al., 2004), root development (Busscher et al., 2001), exchangeable basic and acidic cations (Shutten et al., 2004), soil exchangeable chemistry (Clien et al., 1997), and nutrient budget (Mallarino, 1996). Hence, landscape is important in fertilizer management (Paz-Gonxalez et al., 2000).

M.Sc. Nnenne Bassey Anwanane, Student, Ph.D. Kehinde Olayemi Affinnih, Lecturer (kehkennyy@yahoo.com),Ph.D. John Olajide Olaniyan, Lecturer - Department of Agronomy, Faculty of Agriculture, University of Ilorin, PMB 1515, Ilorin, Kwara State Nigeria 
Soil depth, however, does not have a direct effect on chemical properties and is equally important in fertilizer management because it impacts the rooting depth, which in turn affects plant growth. With emphasis being shifted to precision farming in Nigeria to meet up food requirements of a rapidly growing population, examination of soil properties in different landscape positions is necessary. Potentials of soil can readily be optimized when information on its physical, chemical and biological properties are available (Lawal et al., 2013). However, information on the effect of slope and depth on physical and chemical properties of the soil in the study area is scarce. Consequently, the objective of this study was to study the effects of slope and soil depth on chemical properties of a typical Alfisol.

\section{MATERIAL AND METHODS}

\section{Description of the Study Area}

The study was carried out along a toposequence of soil: upper (N $0827^{\prime} 08.6^{\prime \prime}$ E004 39'42.2", 323 m), middle (N 08 27' 18.7" E004 39' 49.8", $335 \mathrm{~m}$ ) and bottom (N 08 27' 19.8" E004 39' 51.5", $336 \mathrm{~m}$ ) slope at University of llorin Teaching and Research Farm, Ilorin, Kwara State, Nigeria. The vegetation of the area is a forest savanna mosaic with the soils formed over the basement complex (Olaniyan, 2003). Gravelly Alfisols dominate the landscape. The study area had been altered by cultivation though fallowed at the time of sampling. It is located in the Southern Guinea Savanna ecological zone of Nigeria approximately by longitudes $4^{0} 35^{\prime} \mathrm{E}$ and latitude $9^{0} 29^{\prime} \mathrm{N}$ of Nigeria, $307 \mathrm{~m}$ above sea level within a tropical climate characterized by a bimodal rainfall pattern with peaks in June and September and a dry spell between mid-July and August. Annual rainfall ranges from $1000 \mathrm{~mm}-1240 \mathrm{~mm}$. The daily temperature range is $20^{\circ} \mathrm{C}-35^{\circ} \mathrm{C}$ (Kolo et al., 2012).

\section{Soil Sampling and Laboratory Analysis}

Soil Samples from the layers of $0-30 \mathrm{~cm}, 30-60$ $\mathrm{cm}$ and $60-90 \mathrm{~cm}$ were collected from fifteen mini pits dug along the toposequence, five on each of the toposequence. A total of 90 samples (45 disturbed and 45 undisturbed) were collected along the toposequence. From each soil depth, undisturbed samples were collected with metal cylinders of $8.3 \mathrm{~cm}$ height and $5.5 \mathrm{~cm}$ internal diameter. The soil was secured with a piece of calico tied round the cylinder and held firmly with a rubber band. Disturbed samples were also collected with soil auger from each depth. The samples were placed in well labelled polythene bags. The samples (disturbed and undisturbed) were transported to the laboratory for soil physical properties determination using standard laboratory methods and/or computed using established procedures.

Disturbed samples were air-dried, crushed and made to pass through a $2 \mathrm{~mm}$ sieve and used for analysis.
Soil $\mathrm{pH}$ was measured with a glass electrode: samples were diluted in water and $\mathrm{KCl}$ (the ratio of soil to water and $\mathrm{KCl}$ was 1:2.5).

Electrical conductivity was measured with electrical conductivity meter in saturated paste extract as described by Okalebo et al. (2002).

Soil organic carbon was determined using the Wet Oxidation Method of Walkley and Black described by Nelson and Sommers (1982). The percent of organic carbon was multiplied by a factor of 1.724 , following the standard practice that organic matter is composed of $58 \%$ carbon (Brady and Weil, 1999).

Total nitrogen was determined using the micro Kjeldahl method/procedure as described by Bremmer and Mulvaney (1982).

Available phosphorus was determined by the Bray 1 method of Bray and Kurtz (1945) and as described by Murphy and Riley (1962).

Exchangeable bases $(\mathrm{Ca}, \mathrm{Mg}, \mathrm{K}$, and $\mathrm{Na}$ ) were extracted in $1 \mathrm{~N} \mathrm{NH}_{4} \mathrm{OAC}$ (ammonium acetate), at $\mathrm{pH}$ 7. $\mathrm{K}$ and $\mathrm{Na}$ were determined by flame photometer. $\mathrm{Ca}$ and $\mathrm{Mg}$ were determined by the EDTA titration method described by Simard (1993).

Exchangeable acidity of the soil was determined by titration method using $1 \mathrm{~N} \mathrm{KCl}$ extract as described by Rhoades (1982).

Effective Cation Exchange Capacity (ECEC) was the summation of exchangeable bases $(\mathrm{Ca}, \mathrm{Mg}, \mathrm{K}, \mathrm{Na}$ ) and exchangeable acidity.

Percent base saturation was expressed as:

Percent base saturation $=\frac{T E B}{E C E C} \times 100 \%$

Where: TEB = Total Exchangeable Bases; ECEC = Effective Cation Exchange Capacity

Exchangeable sodium percentage was expressed as:

Exchangeable sodium Percentage $=$

$\frac{\text { Exchangeable Na }}{T E B} \times 100 \%$

Sodium adsorption ratio was expressed as:

Sodium adsorption ratio $=\frac{N a^{t}}{\sqrt{\frac{1}{2}\left[C a^{2 t}+M g^{2 t}\right]}}$

Where: $\mathrm{Na}^{+}=$exchangeable sodium, $\mathrm{Ca}^{2+}=$ exchangeable calcium, $\mathrm{Mg}^{2+}=$ exchangeable magnesium

\section{Statistical Analysis}

Soil data collected from the experimental site are in normal distribution and in linear model, thus subjected to Analysis of Variance using SPSS 16.0 edition. The statistical design adopted for the study involving two factors (slope $x$ depth) at three levels each was the $2 \times 3$ 
factorial combinations in a randomized complete block design (RCBD) with five replicates ( $r$ ). The 3 levels of each factors: Depth $\left(D_{0-30} \mathrm{~cm}, D_{30-60} \mathrm{~cm}\right.$ and $\left.D_{60-90} \mathrm{~cm}\right)$, and Slopes (Upper, Middle and Bottom) serve as blocks.

\section{RESULTS AND DISCUSSION}

\section{Effect of Selected Soil Chemical Properties}

Data on selected soil chemical properties along a toposequence are presented in Table 1. There were no significant differences on $\mathrm{pH}$ in water and $\mathrm{KCl}$ along slope, though $\mathrm{pH}$ decreased across slope. However, the $\mathrm{pH}$ values were statistically different with depths. It was generally observed that $\mathrm{pH}$ increased with depth both in water and $\mathrm{KCl}$, with the trend: $6.2<6.8<7.2$ from $0-30$ to $60-90 \mathrm{~cm}$ depth and $6.0<6.6<7.0$ in water and $\mathrm{KCl}$, respectively (Table 1). This could be attributed to the moisture content (Rigg, 1993) as well as eluviation of basic cations down the soil profile (Brady and Weil, 2010). Decomposition of organic matter in form of leaf droppings is a common phenomenon in the $0-30 \mathrm{~cm}$ layer which acidifies the soil as ammonium nitrogen is converted to nitrate (Tisdale et al., 2003). Brady and Weil (2010) had established pH range of 5.5-7.0 as optimal for overall satisfactory availability of plant nutrients. Hence, $\mathrm{pH}$ values obtained are within ideal range for optimum growth and nutrient availability to plants. Esu (1991) attributed the $\mathrm{pH}$ values to the nature of the parent materials on which the soil is developed.

Main effect in Table 1 for electrical conductivity indicated no injury to plant as accumulation of water soluble salts mainly sodium is negligible $\left(<2 \mathrm{dS} \mathrm{m}^{-1}\right)$ (Richards, 1954). There was no significant difference with respect to slope but depth effects were not statistically the same at $p \leq 0.05$ (Table 1). Salinity, though not significant increased with depth: $0.14<0.22<0.25$

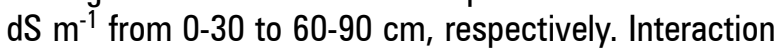
was significant at $p \leq 0.01$ (Table 2) with the $60-90 \mathrm{~cm}$ of the upper slope and $30-60 \mathrm{~cm}$ depth of the middle slope recording the highest value of $0.27 \mathrm{dS} \mathrm{m}^{-1}$.

Total nitrogen contents decreased with depth with the trend $1.25>0.82>0.57 \mathrm{~g} \mathrm{~kg}^{-1}$ which were statistically different at $\mathrm{p} \leq 0.05$ (Table 1). Similarly, effect of slope was significant on nitrogen contents in the soil with the upper slope having the highest $\left(1.03 \mathrm{~g} \mathrm{~kg}^{-1}\right)$ which was statistically different from the middle and lower slopes that were statistically the same (Table 1). This remarkable difference at the upper slope might be attributed to percolating water which tends to move laterally across profile instead of vertically (Esu, 2010). It has been established that water movement in landscapes is the major process responsible for soil development (Gobin et al., 2001). Also, the nitrogen contents were lower than the critical level of $1.5 \mathrm{~g} \mathrm{~kg}^{-1}$ (Enwenzor et al., 1979). Thus, appropriate management practices such as green manuring, fertilizer application etc. are pertinent for soil sustainability. However, interaction of slope and depth was not significant (Table 2).
Soil Organic Matter content $\left(\mathrm{g} \mathrm{kg}^{-1}\right)$ as presented in Tables 1 and 2 indicate that slope, soil depth and the interaction between the effect of slope and soil depth were significant at $5 \%$ probability level. The values obtained showed that it increased across slope and decreased with depth with the following trend: $10.21<13.77<15.63 \mathrm{~g} \mathrm{~kg}^{-1}$ and $20.92>12.94>5.50$ $\mathrm{g} \mathrm{kg}^{-1}$ for slope and depth 1, 2 and 3, respectively. Okusami and Oyediran (1985) observed similar distributions with depth in soils of Ife area in Nigeria. This result implied that the terrain has a steep slope which enhanced accumulation of soil organic matter at the lower slope. Also, cultural practices are more pronounced at the $0-30$ and $30-60 \mathrm{~cm}$. Consequently, the higher organic matter contents at these depths which were statistically different from each other and the $60-90 \mathrm{~cm}$ depth. OC decreased with increasing soil depth, probably due to decreased faunal activities in the underlying horizons as suggested by Browaldh (1995). Total $\mathrm{N}$ was also relatively low in the studied soils and its contents ranged from 0.6 to $1.25 \mathrm{~g} \mathrm{~kg}^{-1}$. Organic matter content of soil supplies about 85 to $90 \%$ of soil nitrogen in unfertilized soils (Amalu, 1997). Although $\mathrm{N}$ is associated with organic matter, its distribution in surface horizon was not in tandem with the $\mathrm{OC}$ along the slope sequence.

Available phosphorus (AP) decreased across slope and depth, although slope difference was not significant $(p<0.05)$ (Table 1). Organic matter was identified as principal source of soil phosphorus for many soils (Evans, 1999). However, irrespective of soil depth, $\mathrm{P}$ levels were higher in upper slope position than the middle and lower slopes probably due to solubilisation of $P$. This finding does not conform to earlier submission of weathering of P-rich parent rock releasing phosphorus into the soil (Lawal et al., 2014).

Exchangeable calcium increased significantly $(p<0.05)$ with depth (Table 1). This to an extent may show the influence of parent materials on distribution of $\mathrm{Ca}^{2+}$ within the soil profile (Brady and Weil, 2010). Increased $\mathrm{Ca}^{2+}$ values in the sub-surface horizon could be attributed to leaching or extraction by roots down the capillary fringes. High $\mathrm{Ca}^{2+}$ values may also be an indication that the soils have a high affinity for calcium, and also that $\mathrm{Ca}^{2+}$ is more strongly bound to the exchange sites than other cations. $\mathrm{Ca}^{2+}$ was rated medium to high. Interaction of slope and depth was also significant with the $60-90 \mathrm{~cm}$ depth of the middle slope recording the highest content $\left(7.86 \mathrm{cmol} \mathrm{kg}^{-1}\right.$ ) (Table 2).

Exchangeable magnesium decreased across slope as follows: $1.65<1.52<1.23 \mathrm{cmol} \mathrm{kg}^{-1}$ (Table 1) which was statistically different from one another. Similarly, magnesium decreased with depth and was also significantly different from one another. Interaction of slope and depth was not significant. Magnesium was rated medium to high. In terms of plant nutrition, $\mathrm{Mg}$ may not be a constraint in the studied soils, but its accumulation in soil may have negative impact on soil structure, lower 
water intake rates and may affect the chemical and biological properties of soil (Donstova and Norton, 2001).

There was no significant difference in exchangeable potassium concentration with slope (Table 1). However, exchangeable potassium (K) content was significantly different with depth $(p<0.05)$. Exchangeable $\mathrm{K}$ decreased from $0-30 \mathrm{~cm}\left(0.28 \mathrm{cmol} \mathrm{kg}^{-1}\right)$ to $30-60 \mathrm{~cm}$ $\left(0.14 \mathrm{cmol} \mathrm{kg}^{-1}\right)$ which was not statistically the same (Table 1). There was, however, no significant difference in the exchangeable $\mathrm{K}$ of the $30-60 \mathrm{~cm}$ and $60-90 \mathrm{~cm}$ depth $\left(0.15 \mathrm{cmol} \mathrm{kg}{ }^{-1}\right)$. Interaction between the effect of slope and soil depth was significant at $5 \%$ probability level (Table 2).

Exchangeable sodium in the upper and bottom slopes recorded the highest $\left(0.15 \mathrm{cmol} \mathrm{kg}^{-1}\right)$ concentration which was statistically different from the middle slope $\left(0.11 \mathrm{cmol} \mathrm{kg}^{-1}\right)$. Effect of depth and interaction was not significant at $5 \%$ level of probability (Tables 1 and 2).

Total Exchangeable Bases $(\mathrm{cmol} / \mathrm{kg})$ presented in Tables 1 and 2 indicate that slope and interaction between the effect of slope and soil depth were significant at $5 \%$ probability level. Slopes at various levels were statistically different from one another with the trend: $7.41<8.09>4.99 \mathrm{cmol} \mathrm{kg}^{-1}$ from the upper to lower slope, respectively (Table 1). Similarly, the 60-90 $\mathrm{cm}$ depth of the upper slope has the highest TEB (9.07

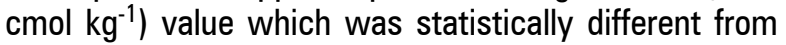
others (Table 2).

Values of exchangeable acidity in the middle slope recorded the highest $\left(0.93 \mathrm{cmol} \mathrm{kg}^{-1}\right)$ which was statistically different from the bottom slope $\left(0.62 \mathrm{cmol} \mathrm{kg}^{-1}\right)$ and upper slope $\left(0.56 \mathrm{cmol} \mathrm{kg}^{-1}\right)$ which are statistically at par (Table 1). Low total acidity values are associated with high $\mathrm{pH}$ values and indicate low acid weathering in the soils. Interaction of slope and depth was significant.

Effective cation exchange capacity in the middle slope recorded the highest $\left(9.02 \mathrm{cmol} \mathrm{kg}^{-1}\right)$ followed by those in the upper slope $\left(7.97 \mathrm{cmol} \mathrm{kg}^{-1}\right)$ and lastly the bottom slope $\left(5.61 \mathrm{cmol} \mathrm{kg}^{-1}\right.$ ) (Table 1). The effective cation exchange capacity values obtained were low which implied that the soil would acidify quickly. Effective cation exchange capacity in both upper and middle slope levels showed an increase in values with depth but in the case of the bottom slope, a decrease was recorded as depth increases. Slope, soil depth and interaction between the effect of slope and soil depth were significant at $5 \%$ probability level with slope and soil depth at various levels statistically different from one another (Tables 1 and 2).

Table 1. Main effects of slope and depth on selected chemical properties of Unilorin Teaching and Research Farm, Ilorin, Nigeria

Tablica 1. Glavni učinci nagiba i dubine na odabrana kemijska svojstva na Unilorin Teaching and Research Farm, Ilorin, Nigerija

\begin{tabular}{|c|c|c|c|c|c|c|c|c|c|c|c|c|c|c|c|c|}
\hline Parameters & $\begin{array}{c}\mathrm{pH} \\
\text { water }\end{array}$ & $\begin{array}{l}\mathrm{pH} \\
\mathrm{KCl}\end{array}$ & $\mathrm{EC}$ & $\mathrm{OM}$ & TN & AP & Ex. Ca & $\begin{array}{l}\text { Ex. } \\
M g\end{array}$ & Ex. $K$ & Ex. $\mathrm{Na}$ & TEB & EA & ECEC & BS & ESP & SAR \\
\hline \multicolumn{17}{|l|}{ Slope (S) } \\
\hline Upper & 6.71 & 6.53 & 0.20 & $10.21 \mathrm{c}$ & $1.03 a$ & 11.07 & $5.22 b$ & $1.65 a$ & 0.19 & $0.15 a$ & $7.41 \mathrm{~b}$ & $0.56 \mathrm{~b}$ & $7.97 \mathrm{~b}$ & $93.25 a$ & $2.16 b$ & $0.09 a$ \\
\hline Middle & 6.77 & 6.56 & 0.21 & $13.77 b$ & $0.74 b$ & 10.44 & $6.25 a$ & $1.52 \mathrm{a}$ & 0.19 & $0.11 b$ & $8.09 a$ & $0.93 a$ & $9.02 a$ & $90.02 b$ & $1.5 c$ & $0.06 \mathrm{~b}$ \\
\hline Lower & 6.74 & 6.50 & 0.20 & $15.63 a$ & $0.85 b$ & 10.32 & $3.43 c$ & $1.23 b$ & 0.18 & $0.15 a$ & $4.99 c$ & $0.62 b$ & $5.61 c$ & $87.67 \mathrm{c}$ & $3.13 a$ & $0.10 \mathrm{a}$ \\
\hline $\mathrm{SE} \pm$ & 0.44 & 0.06 & 0.01 & 0.58 & 0.06 & 0.28 & 0.14 & 0.09 & 0.01 & 0.01 & 0.14 & 0.03 & 0.13 & 0.42 & 0.14 & 0.00 \\
\hline \multicolumn{17}{|l|}{ Depth (D) } \\
\hline $0-30 \mathrm{~cm}$ & $6.18 c$ & $5.97 c$ & $0.14 c$ & $20.92 a$ & $1.25 a$ & $13.66 a$ & $3.87 \mathrm{c}$ & $1.98 a$ & $0.28 a$ & 0.15 & 6.27 & $0.41 \mathrm{c}$ & $6.68 c$ & $93.92 a$ & $2.40 a$ & $0.088 a$ \\
\hline $30-60 \mathrm{~cm}$ & $6.83 b$ & $6.58 \mathrm{~b}$ & $0.22 b$ & $12.94 \mathrm{~b}$ & $0.82 b$ & $9.79 b$ & $5.25 b$ & $1.42 b$ & $0.14 b$ & 0.13 & 6.94 & $0.61 \mathrm{~b}$ & $7.55 b$ & $91.90 \mathrm{~b}$ & $1.98 b$ & $0.070 \mathrm{~b}$ \\
\hline $60-90 \mathrm{~cm}$ & $7.21 \mathrm{a}$ & 7.03a & $0.25 a$ & $5.50 \mathrm{c}$ & $0.57 c$ & $8.42 c$ & $5.72 a$ & $1.00 \mathrm{c}$ & $0.15 b$ & 0.14 & 7.22 & $1.08 \mathrm{a}$ & $8.30 \mathrm{a}$ & $85.33 c$ & $2.46 a$ & $0.090 \mathrm{ab}$ \\
\hline $\mathrm{SE} \pm$ & 0.44 & 0.06 & 0.01 & 0.58 & 0.06 & 0.28 & 0.14 & 0.09 & 0.01 & 0.01 & 0.14 & 0.03 & 0.13 & 0.42 & 0.14 & 0.00 \\
\hline \multicolumn{17}{|l|}{ Interaction } \\
\hline$S \times D$ & NS & NS & $* *$ & $* *$ & NS & * & $* * *$ & NS & $* *$ & NS & $* * *$ & * & $* * *$ & $* * *$ & $* * *$ & NS \\
\hline
\end{tabular}

Means with different letters along the same row are statistically different from each other at $\mathrm{p} \leq 0.05$. NS $=$ Not significant, ${ }^{*},{ }^{*}$ and ${ }^{* * *}=$ significant at the $5 \%, 1 \%$ and $0.01 \%$ level of probability. $\mathrm{EC}=$ electrical conductivity in $\mathrm{dS} \mathrm{m}^{-1}, \mathrm{OM}=$ organic matter in $\mathrm{g} \mathrm{kg}^{-1}, \mathrm{AP}=$ available phosphorus in meq kg ${ }^{-1}, \mathrm{Ex}$. Ca $=$ exchangeable calcium in $\mathrm{cmol} \mathrm{kg}^{-1}$, Ex. $\mathrm{Mg}=$ exchangeable magnesium in $\mathrm{cmol} \mathrm{kg}^{-1}$, Ex. $\mathrm{Na}=$ exchangeable sodium in $\mathrm{cmol} \mathrm{kg}^{-1}$, Ex. $\mathrm{K}=$ exchangeable potassium in $\mathrm{cmol} \mathrm{kg}^{-1}, \mathrm{EA}=$ exchangeable acidity in $\mathrm{cmol} \mathrm{kg}^{-1}, \mathrm{ECEC}=$ effective cation exchange capacity in $\mathrm{cmol} \mathrm{kg}^{-1}, \mathrm{BS}=$ base saturation in $\%, \mathrm{ESP}=$ exchangeable sodium percentage in $\%$, SAR $=$ sodium adsorption ratio 
Table 2. Interaction of slope and soil depth on selected chemical properties along a toposequence of Unilorin Teaching and Research Farm

Tablica 2. Interakcija nagiba i dubine na odabrana kemijska svojstva duž toposekvence na llorin Teaching and Research Farm

\begin{tabular}{|l|c|c|c|c|c|c|c|c|c|c|}
\hline \multicolumn{1}{|c|}{ Slope } & Depth & EC & OM & AP & Ex.Ca & Ex.K & TEB & ECEC & BS & ESP \\
\hline Upper & $0-30$ & $0.12 \mathrm{a}$ & $16.39 \mathrm{~b}$ & 14.82 & 3.56 & 0.25 & 6.12 & 6.45 & 94.86 & 2.7 \\
\hline Upper & $30-60$ & $0.21 \mathrm{~d}$ & $8.97 \mathrm{e}$ & 9.28 & 5.44 & 0.15 & 7.29 & 7.77 & 93.74 & 1.99 \\
\hline Upper & $60-90$ & $0.27 \mathrm{e}$ & $4.03 \mathrm{~g}$ & 8.36 & 7 & 0.17 & 9.07 & 9.99 & 90.82 & 1.7 \\
\hline Middle & $0-30$ & $0.11 \mathrm{a}$ & $23.89 \mathrm{a}$ & 13.74 & 3.58 & 0.29 & 6.21 & 6.67 & 93.05 & 2.02 \\
\hline Middle & $30-60$ & $0.27 \mathrm{e}$ & $15.25 \mathrm{c}$ & 9.86 & 6.78 & 0.14 & 8.43 & 9.3 & 90.6 & 1.21 \\
\hline Middle & $60-90$ & $0.24 \mathrm{~d}$ & $4.20 \mathrm{~g}$ & 8.39 & 7.86 & 0.16 & 9.25 & 10.62 & 87.02 & 1.37 \\
\hline Lower & $0-30$ & $0.19 \mathrm{c}$ & $24.00 \mathrm{a}$ & 12.22 & 4.47 & 0.3 & 6.51 & 6.97 & 93.49 & 2.35 \\
\hline Lower & $30-60$ & $0.18 \mathrm{~b}$ & $14.60 \mathrm{~d}$ & 10.22 & 3.52 & 0.12 & 5.09 & 5.57 & 91.37 & 2.74 \\
\hline Lower & $60-90$ & $0.24 \mathrm{~d}$ & $8.28 \mathrm{f}$ & 8.51 & 2.3 & 0.12 & 3.36 & 4.3 & 78.16 & 4.31 \\
\hline SE \pm & & 0.01 & 0.34 & 0.16 & 0.08 & 0.005 & 0.0787 & 0.0767 & 0.2 & 0.08 \\
\hline
\end{tabular}

Means with different letters along the same column are statistically different from each other at $\mathrm{p} \leq 0.05$. $\mathrm{EC}=$ electrical conductivity in $\mathrm{dS} \mathrm{m}^{-1}$, $0 \mathrm{M}=\mathrm{organic}^{-1}$ matter in $\mathrm{g} \mathrm{kg}^{-1}, \mathrm{AP}=$ available phosphorus in meq $\mathrm{kg}^{-1}, \mathrm{Ex} . \mathrm{Ca}=$ exchangeable calcium in $\mathrm{cmol} \mathrm{kg}^{-1}, \mathrm{Ex} . \mathrm{K}=$ exchangeable potassium in $\mathrm{cmol} \mathrm{kg}^{-1}$, TEB $=$ total exchangeable bases in $\mathrm{cmol} \mathrm{kg}^{-1}, \mathrm{ECEC}=$ effective cation exchange capacity in $\mathrm{cmol} \mathrm{kg}^{-1}, \mathrm{BS}=$ base saturation in $\%$, ESP $=$ exchangeable sodium percentage in $\%$

Base saturation in the upper slope recorded the highest value $(93.25 \%)$ followed by those in the middle slope $(90.02 \%)$ and lastly the bottom slope $(87.67 \%)$. High values obtained for base saturation in this study imply that the soil is nearly saturated with exchangeable cations, which is a characteristic of a typical Alfisol ( $>35 \%$ in argilic horizon) which reflects dominance of non-acid cations on the exchange sites of the soil (Lawal et al., 2014). Slope, soil depth and interaction between the effect of slope and soil depth were significant at $5 \%$ probability level with slope and soil depth at various levels statistically different from one another (Table 1). Surface horizons have more variable composition being area of active depositional processes. The base saturation decreases concomitantly with increase in exchangeable acidity. However, increase in exchangeable cations $(\mathrm{K}, \mathrm{Ca}, \mathrm{Mg})$ and base saturation have been reported (Kretzschmar et al., 1991) with addition of organic amendment.

Exchangeable sodium percentage was also significant at $5 \%$ level of probability for slope, soil depth and interaction (Tables 1 and 2). Exchangeable sodium percentage in the bottom slope recorded the highest values followed by those in the upper slope and lastly followed by those in the middle slope which were statistically different from one another.

Data for sodium adsorption ratio calculated implied that the soils studied have no salt problem. Slope, soil depth and interaction between the effect of slope and soil depth were significant at $5 \%$ probability level. Values of sodium absorption ratio in the bottom slope level were the highest $(0.10)$ followed by those in the upper slope level (0.09) which are statically at par, but were statistically different from the middle slope level which recorded the lowest value (0.06) (Table 1). In the same manner, soil depth at $0-30 \mathrm{~cm}$ and $30-60 \mathrm{~cm}$ are statistically different from one another.

\section{CONCLUSION}

Results of this study showed the influence of depth on the selected chemical properties, with the three soil depth: 0-30, 30-60 and 60-90 cm levels been important in evaluating soil fertility status of Unilorin Teaching and Research Farm. However, soil organic matter, total Nitrogen, exchangeable bases $\mathrm{Ca}, \mathrm{Mg}$, $\mathrm{Na}$ and $\mathrm{K}$, exchangeable acid, effective cation exchange capacity, base saturation, exchangeable sodium percentage and sodium absorption ratio were affected by slope, while interaction of slope and depth were significant for electrical conductivity, soil organic matter, total nitrogen, available phosphorus, exchangeable bases, exchangeable acid, effective cation exchange capacity, base saturation, exchangeable sodium percentage and sodium absorption ratio. Thus, management options proffered with respect to the chemical properties along a toposequence with kin interest on depth is panacea for sustainable crop and soil productivity in this area.

\section{REFERENCES}

1. Adeoye, G.0., Agboola, A.A. (1985): Critical levels for soil $\mathrm{pH}$, available $\mathrm{P}, \mathrm{K}, \mathrm{Zn}$ and Maize Year Leaf content of $\mathrm{P}_{1} \mathrm{Cu}$ and $\mathrm{Mn}$ in sedimentary soils of south western Nigeria. Fertilizer Research, 6: 65-71.

2. Amalu, U.C. (1997): Properties and relationship among fertility indices of some coastal plain soil under rubber 
trees. Global Journal of Pure and Applied Sciences, 4(4): 12-71.

3. Asadu, C.L.A., Nnaji, G.U., Ezeaku, P.I. (2012): Conceptual issues in pedology. University of Nigerian Press Limited, University of Nigeria, Nsukka, Nigeria, pp. 34-57.

4. Bhatti, A.U., Mulla, D.J., Frasier, B.E. (1991): Estimation of Soil Properties and Wheat Yields in a Complex Eroded Hill Using Geostatistics and Thematic Mapper Images. Remote Sens. Environ, 37: 181-191.

5. Brady, C.N., Weil, R.R. (1999): The nature and properties of soil. $12^{\text {th }}$ edition, Prentice Hall, Englewood Cliffs, nj.

6. Brady, N.C., Weil, R. (2010): Elements of the nature and properties of soils. $3^{\text {rd }}$ edition. Pearson Education, Inc., Upper Saddle River, New Jersey, pp. 74-89.

7. Bray, R.H., Kurtz, L.T. (1945): Determination of total, organic and available forms of Phosphorus. Soil Sci., 59: 3945.

8. Bremmer, J.M., Mulvaney, C.S. (1982): Nitrogen-total. In: Page A.L., Miller R.H., Keeney D.R. (Ed) Methods of soil analysis, chemical and microbiological properties, Part 2, $2^{\text {nd }}$ edition. ASA-SSSA, Madison, WI, pp 595624.

9. Browaldh, M. (1995): The influence of trees on nitrogen dynamics in an agrisilvicultural system in Sweden. Agroforestry System, 30(3): 301-313.

10. Bruand, A., Hartmann, C., Ratana-Anupap, S., Poss, R., Hardy, M. (2004): Composition, fabric and porosity of an Arenic Haplustalf of northeast Thailand: Relation to penetration resistance. Soil Science Society of America Journal, 68(1): 185-193.

11. Busscher, W.J., Federick, J.R, Bauer, P.J. (2001): Effect of Penetration Resistance and Timing of Rain on Grain Yield of a Narrow-Row Corn on a Coastal Plain Loamy Sand. Soil Till. Res. 63:15-24.

12. Clien, Y.J., Lee, D.Y., Guo, H.Y., Honng, K.H. (1997): Geostatistical Analysis of Soil Properties of Mid -West Taiwan Soils. Soil Science, 162: 291-298.

13. Donstova, K.M., Norton, L.D. (2001): Effect of exchangeable Ca:Mg ratio in soil clay flocculation, infiltration and erosion. In: Sustaining the Global Farm. D.E. Stott, R.H. Mohtar and G.C. Steintardt (eds.). Selected papers from $10^{\text {th }}$ International Soil Conservation Organization Meeting held May 24-29, 1999 at Purdue University and USDAARS National Soil Erosion Research Laboratory, pp. 580585.

14. Enwenzor, W.O., Udo, E.J., Usoroh, N.J., Ayotade, K.A., Adepetu, J.A., Chudu, V.O., Udegbe, C.J. (1979): Fertilizer Use and Management Practices for Crops in Nigeria (Series No. 21). Produced by Fertilizer Procurement and Distribution Division of the Federal Ministry of Agriculture, Water Resources and Rural Development, Lagos.

15. Esu, I.E. (1991): Detailed soil survey of NIHORT Farm at Bunkure, Kano State, Nigeria. Institute for Agricultural Research, Ahmadu Bello University, Zaria, Nigeria, 1-72.

16. Esu, I.E., Akpan Idiok, A.U., Eyong, M.O. (2008): Characterization and Classification of Soils along Typical Hillslope in Afikpo Area of Ebonyi State, Nigeria. Nigeria Journal of Soil and Environmental Resources, 8: 1-16. doi: http://dx.doi.org/10.4314/njser.v8i1.52050
17. Esu, E. (2010): Soil characterization, classification and survey. HEBN Publishers, Plc, Ibadan, Nigeria, 232 pp.

18. Gobin, S. J. P., Biesta, P., De Steenwinkel, J. E. M., Datema, G., and Van den Elsen, P. J. (2002). CREB provides for an alternative pathway of HLA-G transactivation. J. Biol. Chem. 277, 39525-39531.

19. Kalivas, D.P., Triantakon D.P., Kotlias, V.J (2012). Spatial prediction of 2 soils properties using topographic information. Global Nest: Int.J., 4:41-49.

20. Kolo, E., Takim, F. O. and Fadayomi, 0. (2012). Influence of planting date and weed Management practice on weed emergence, growth and yield of maize (Zea mays L.) in Southern Guinea Savanna of Nigeria. African Crop Science Journal, 9(4): 615-627.

21. Kretzschmar, R.M., Hafner, H., Bationo, A., Marschner, H. (1991): Long and short term effects of crop residues on aluminium toxicity, phosphorus availability and growth of pearl millet in an acid sandy soil. Plant Soil, 135: 215-223

doi: http://dx.doi.org/10.1007/BF02150052

22. Lawal, B.A., Ojanuga, A.G., Tsado, P.A., Mohammed, A. (2013): Characterization, Classification and Agricultural Potentials of Soils on a Toposequence in Southern Guinea Savanna of Nigeria. International Journal of Biological, Veterinary, Agricultural and Food Engineering, 7(5): 148-152.

23. Lawal, B.A., Tsado, P.A., Eze, P.C., Idefoh, K.K., Zaki, A.A., Kolawole, S. (2014): Effect of Slope Positions on some Properties of Soils under a Tectona grandis Plantation in Minna, Southern Guinea Savanna of Nigeria. International Journal of Research in Agriculture and Forestry, 1(2): 37-43.

24. Mallarino, A.P. (1996): Spatial Patterns of Phosphorus and Potassium in Non-Tilled Soils for Two Sampling Scales. Soil Science Society of America Journal, 60: 473-1481.

25. Murphy, J., Riley, J.P. (1962): A modified single solution method for the determination of phosphate in natural water. Anal. Chem. Acta, 27: 31-36. doi: http://dx.doi.org/10.1016/S0003-2670(00)88444-5

26. Nelson, D.W., Sommers, L.E. (1982): Total carbon, organic carbon and organic matter. In: Page, A. L., Miller, R.H., and Keeney, D.R. (eds): Methods of Soil Analysis: Chemical and Microbiological Properties. Part 2, $2^{\text {nd }}$ edition. ASA-SSSA Madison, WI pp 539-579.

27. Ogban, P.I., Babalola, O., Okoji, A.M. (1999): Profile Characteristics of a typical toposequence in Southern Nigeria. Africa Soils, 28: 147-165.

28. Okusami, T.A., Oyediran, G.0. (1985): Slope-Soil Relations on an Aberrant Toposequence in Ife Area of South Western Nigeria: Variabilities in Soil Properties. Ife J. Agric., lle-Ife, 7(1-2): 1-13.

29. Olaniyan, J.0. (2003): An Evaluation of the Soil Map of Nigeria for Land use Planning in Kwara State. Ph.D. thesis Dept. of Agronomy, University of Ibadan, Nigeria, $211 \mathrm{pp}$.

30. Okalebo J. R., Gathua K. W., Woomer P. L. (2002). Laboratory Methods of Soil and Plant Analysis: A Working Manual, KARI, SSSEA, TSBF, SACRED Africa, Second Edn Nairobi: Moi University, 128. 
31. Osodeke, V.E., Osondu, N.E. (2006): Phosphorus distribution along a toposequence of a coastal sand parent material in southeastern Nigeria. Agricultural J., 1(3): 167-171.

32. Paz-Gonzalez, A., Vierira, S.R., Taboada-Castro, M.T. (2000): The Effect of Cultivation on the Spatial Variability of Selected Properties of an Umbric Horizon. Geoderma, 97: 273-292

doi: http://dx.doi.org/10.1016/S0016-7061(00)00066-5

33. Richard, R.B., Allison, E.B., Bower, B.B (1954): Diagnosis and Improvement of Saline and Alkaline soils. Agriculture Handbook No.60. United States Department of Agriculture.

34. Rigg, L. (1993): Study of soil properties along a hillslope in parson's parcel bouldeb, co. Geography 4411 Methods of Soil Analysis Fall Semester, 1993. Department of
Geography University of Colorado Boulder, Co. Retrieved online on the $30^{\text {th }}$ May, 2016.

35. Rhoades, J.D. (1982): Cation exchange capacity. In: Page, A.L., Miller, R.H., Keeney, D.R. (Ed) methods of soil analysis: chemical and microbiological properties. Part 2, $2^{\text {nd }}$ edn. ASA-SSSA, Madison, WI, PP 149-158.

36. Simard, R.R. (1993): Ammonium acetate-extractable elements. In: Carter, M.R. (Ed) soil sampling and methods of analysis. Lewis publishers, Boca Raton, F.L., PP 39-42.

37. Schutten, J., Dainty, J. \& Davy, A.J. (2004) Waveinduced hydraulic forces on submerged aquatic plants in shallow lakes. Annals of Botany, 93: 333-341.

38. Tisdale, S.L., Nelson, W.L., Beaton, J.D., Havlin, J.L. (2003): Soil fertility and fertilizers. $5^{\text {th }}$ ed. New Delhi: Prentice Hall of India Private Limited 634 p.

\section{UTJECAJ NAGIBA I DUBINE NA KEMIJSKA SVOJSTVA TIPIČNOG ALFISOLA}

\section{SAŽETAK}

Mogućnosti gospodarenja koje se nude u pogledu kemijskih svojstava uz toposekvencu ključ su održive produktivnosti usjeva $i$ tla, budući da su nutritivni status i svojstva tla povezani s topografijom površine zemljišta. Provedeno je istraživanje kako bi se procijenio utjecaj nagiba i dubine na odabrana kemijska svojstva tla na znanstveno-nastavnom pokušalištu Sveučilišta Ilorin 2013. Označene su i uzorkovane tri točke: gornja, srednja i donja padina, uz toposekvencu, s prosječnom udaljenošću od $200 \mathrm{~m}$, za analizu tla na dubinama 0-30 cm, 30-60 cm i 60-90 cm pomoću sonde za uzorkovanje i svrdla. Kemijska svojstva tla, koja uključuju pH vode, $\mathrm{pH} \mathrm{KCl}$, električnu vodljivost, organsku tvar, ukupni dušik, raspoloživi fosfor, izmjenjive baze (Ca, $\mathrm{Mg}, \mathrm{K}, \mathrm{Na})$, izmjenjivu kiselost, efektivni kapacitet izmjene kationa, zasićenost tla bazama, postotak izmjenjivoga natrija i omjer adsorpcije natrija, utvrđeni su u laboratoriju/izračunati kasnije. Dobiveni podaci podvrgnuti su analizi ANOVA pomoću 2x3 faktorske kombinacije čimbenika - nagib i dubina - u slučajnome bloknome rasporedu (RCBD) s pet replikacija. Rezultati utjecaja nagiba i dubine tla na kemijska svojstva tla pokazali su da je dubina tla utjecala na sva mjerena kemijska svojstva tla, osim izmjenjivoga natrija. Na vrijednost pH (i vode i KCl), električnu vodljivost, raspoloživi fosfor i izmjenjivi kalij nagib nije utjecao. Također, na pH, izmjenjivi magnezij i natrij interakcija između učinka nagiba i dubine tla nije utjecala.

Ključne riječi: nagib, dubina, kemijska svojstva, Alfisol

(Received on 10 November 2015; accepted on 14 July 2017 - Primljeno 10. studenoga 2015.; prihvaćeno 14. srpnja 2017.) 